\title{
Preparation and Characterization of d.c.-Plated Nanocrystalline Nickel Deposits
}

\author{
B. SzEPTYCKA AND D. DEREWNICKA*
}

Institute of Precision Mechanics, Duchnicka 3, 01-796 Warsaw, Poland

\begin{abstract}
The microstructure, microhardness, corrosion, and wear resistance of d.c.-plated $\mathrm{Ni}$ electrodeposits prepared from different types of electrolyzing Watts-type baths, without or with organic compounds, ceramic powder - $\mathrm{SiC}$ and polymer - polytetrafluoroethylene (PTFE), on Cu substrate, which was subsequently removed from the deposits, were investigated. With the change of the type of bath, the deposit grain size was found to decrease markedly, e.g. deposits with an average grain size of about $50 \mathrm{~nm}$ could be produced from a bath containing $45 \mathrm{~g} / \mathrm{dm}^{3} \mathrm{Ni}^{2+}$ ions, $5 \mathrm{~g} / \mathrm{dm}^{3} \mathrm{SiC}$, and $20 \mathrm{~g} / \mathrm{dm}^{3}$ PTFE. The surface morphology on the bath side of the electrodeposited $\mathrm{Ni}$ or $\mathrm{Ni}-\mathrm{SiC}-\mathrm{PTFE}$ foils was characteristic of the type of bath, and its roughness correlated well with the observed grain size. Microhardness and wear resistance increased with decreasing grain size, as expected. On discussing the factors controlling deposit grain size, it is concluded that the $\mathrm{Ni}^{2+}$ ion content in the bath and the presence of organic compounds may have a decisive role.
\end{abstract}

PACS numbers: 81.07.-b, 68.37.Lp, 68.60.--p

\section{Introduction}

Although electrodeposition is a very effective method of synthesizing nanocrystalline metals, it is cited less often than other methods. The advantages of electrodeposition are numerous and include:

- The possibility of synthesizing a large number of pure metals, alloys, and composites with grain sizes as small as $10 \mathrm{~nm}$;

- Low investment costs and fast production;

${ }^{*}$ corresponding author 
- Production of nanomaterials directly in their full volume without further processing (in contrast with, for example, the sol-gel method in which the components are produced first, then combined);

- A fast track from laboratory to technical scales.

Moreover, electrodeposited nickel foils have unique properties such as: high density, low porosity, excellent adhesion, and high corrosion resistance [1].

They are also highly wear resistant and are used to regenerate heat exchangers, as electronic connectors, catalysis for hydrogen oxidation and evolution reaction electrodes [2]. Nanonickel has applications in the production of capacitors, and is used to build superlattices [3-6] characterized by the gigantic magnetoresistance (GMR) effect. Nanonickel powder has also been used in mixtures with fullerenes in the production of diamonds [7].

Electrodepositon of nanonickel may be done under d.c. [8] or pulse [9] plating. Nanocrystalline alloys of $\mathrm{Ni}-\mathrm{W}$ have also been electrodeposited [10], as have composite nanonickel foils with $\mathrm{Al}_{2} \mathrm{O}_{3}$ and $\mathrm{TiO}_{2}$ [11] and with $\mathrm{SiC}$ [12]. Celis et al. [13] described a mathematical model for the electrolytic codeposition of inert particles with a metallic matrix. The deposition strategies for the incorporation of particles into growing metal deposits can be divided in two groups - physical dispersion and adsorption of cationic surfactants at the particle surface in order to give it a positive charge (Helle and Walsh [14]). Szczygiel [15] described the influence of the concentration $\mathrm{Ni}^{2+}$ ions and $\mathrm{SiC}$ on adsorption $\mathrm{Ni}^{2+}$ ions into $\mathrm{SiC}$ surface. The same author [16] researched influence of dispersion particles $\mathrm{SiC}$ on the kinetics of deposition of composite coatings. Celis and Franser [17] present new insight leading to improved process control of the electrolytic codeposition of particles with metal. Ramesh Babu and Mohan [18] described the electrochemical behavior of systems $\mathrm{Ni}^{2+}-\mathrm{PTFE}$.

In this paper we describe d.c.-plated nickel foils differing in grain size and properties. In the study we used low-concentration baths with various organic additives.

\section{Experimental}

\subsection{Sample preparation}

In the experiments on d.c.-plating of nickel foils and hybrid composite nickel foils we used low-concentration baths ( $\mathrm{L}-\mathrm{CB}$ ) with a basic composition of: $130 \mathrm{~g} / \mathrm{dm}^{3} \mathrm{NiSO}_{4} \cdot 7 \mathrm{H}_{2} \mathrm{O}$ p.g., $70 \mathrm{~g} / \mathrm{dm}^{3} \mathrm{NiCl}_{2} \cdot 6 \mathrm{H}_{2} \mathrm{O}$ p.a., $45 \mathrm{~g} / \mathrm{dm}^{3} \mathrm{H}_{3} \mathrm{BO}_{3}$ p.g. (p.a. - analitycal reagant, p.g. - pure).

The bath was prepared with distilled water in a routine manner, oxidized and pre-electrolyzed in order to remove contaminants, after which the proper components for each type of bath were added. A bath with no additives served as the control. Moreover, the KGN-97 [19] bath (commercial low-concentration bath with a high ability of microsmoothing), which contained WRN addition to the basic salts, 
was used. WRN is a mixture of several organic compounds such as alkynylenols, quaternary pyridinium salts, saccharin. Bath HKT-2000 [20] (low-concentration hybrid nickel plating bath) was also used. It contained $5 \mathrm{~g} / \mathrm{dm}^{3} \mathrm{SiC} 1000$ and $20 \mathrm{~g} / \mathrm{dm}^{3}$ PTFE ( 0.1 to 0.3 micron particles) and, as a wetting additive, a cationic high-fluoride surfactant (WFK) and HRN as an addition agent (mixture of several organic compounds - to be patent). The particles $\mathrm{SiC}$ and PTFE were dispersed (each separated) into a $1 \%$ aqueous solution of wetting agent using a porcelain mortar. These disperses were treated with $50 \mathrm{~cm}^{3}$ of each bath, this was stirred and transferred into an electrolytic cell with such a bath. Nickel layers were deposited at a current density of $4 \mathrm{~A} / \mathrm{dm}^{2}$ at a temperature of $45^{\circ} \mathrm{C}$ for 30 min with mixing at the appropriate $\mathrm{pH}$ for the process. The substrate was a copper sheet degreasing with Vienna lime and pickling with 1:1 hydrochloric acid and then passivation so it was possible to remove the deposited nickel foil. A two-electrode electrolytic cell was used. An electrolytic Ni plate was used as anode, placed parallel to the cathode at a distance of $80 \mathrm{~mm}$. The large anode to cathode surface area ratio ensured a uniform current distribution.

\subsection{Techniques for investigating the deposit properties}

The bright-field transmission electron micrographs were taken for examination of the structure of nanocrystalline deposits. Thin foils for TEM examination were prepared by pulse electrolytic thinning using an electrolyte comprising of $10 \mathrm{vol} . \%$ perchloric acid in methanol at $0^{\circ} \mathrm{C}$ and $20 \mathrm{~V} \mathrm{p}$-c (pulse current).

The microhardness of the deposited layers was measured using Vickers' method and a REICHERT MF3 microhardness tester at a load of $0.05 \mathrm{~kg}$.

Brightness was measured with a Johansonn 8510-1 glossmeter. The roughness of the nickel foils was evaluated using a Taylor-Hobson profilograph.

In order to determine wear resistance the nickel foils were tested using a technique based on a measuring system comprising a flat surface and ball. The layers were subjected to wear by dry slide friction using a $40 \mathrm{~mm}$ diameter ball at an angle of $40^{\circ}$. The pressure of the ball at the point of contact was $1.3 \mathrm{~N}$, duration of friction - $60 \mathrm{~min}$. On the basis of the wear traces and measurement of their diameter, the depth of the wear was calculated, which was a measure of wear resistance.

Resistance to corrosion was evaluated using a voltammetric method in a three-electrode system. The test was conducted in $0.5 \mathrm{M}$ non-deoxidization solution of sodium chloride.

\section{Results and discussion}

\subsection{Structural studies}

Very large grains distinguished the nickel layer deposited in a low-concentration bath (Fig. 1). The majority of the grains were $0.4-0.8 \mu \mathrm{m}$ in size. Lattice 


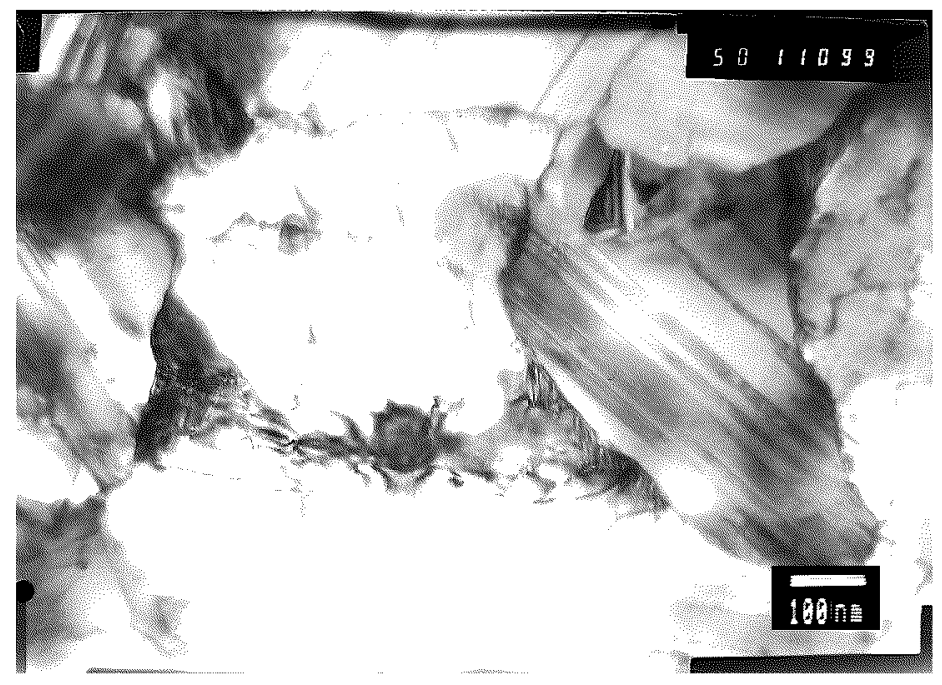

Fig. 1. TEM picture of the microstructure of $\mathrm{Ni}$ foil d.c.-plated from a low-concentration bath.

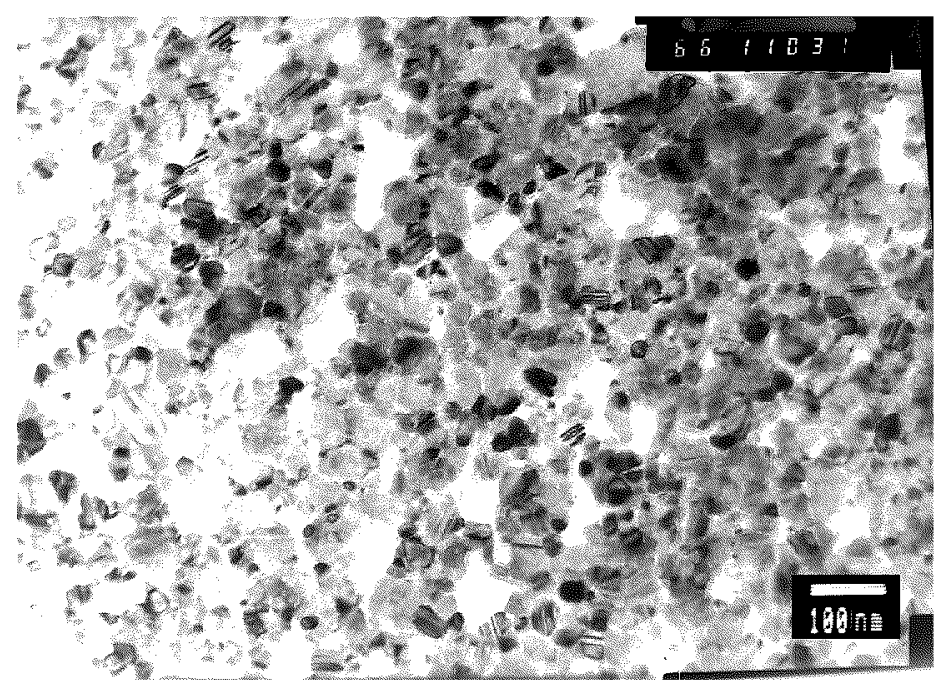

Fig. 2. TEM picture of the microstructure of Ni foil d.c.-plated from bath KGN-97.

defects and subgrains (segmentation and lamellar arrangement) were visible. The grains were irregular in shape. The relatively low current density and consequent small degree of depletion of $\mathrm{Ni}^{2+}$ concentration at the cathode/electrolyte interface and lack of organic additives were probably the main causes of the unrestricted electrocrystallization of nickel. There were no factors restricting the grain growth, so the grain size was limited mainly by the frequency nucleation, this frequency 
declines as current density increases. The studied bath composition and electrocrystallization conditions produced grains with an average size of $600 \mathrm{~nm}$. The organic additives WRN completely changed the structure of the deposited nickel layer and grain size. Very small grains, $10-50 \mathrm{~nm}$ (Fig. 2), were found in the layer and the surface of the sample was very smooth. Surface texture was not visible under a scanning electron microscope at magnifications up to $5000 \mathrm{x}$.

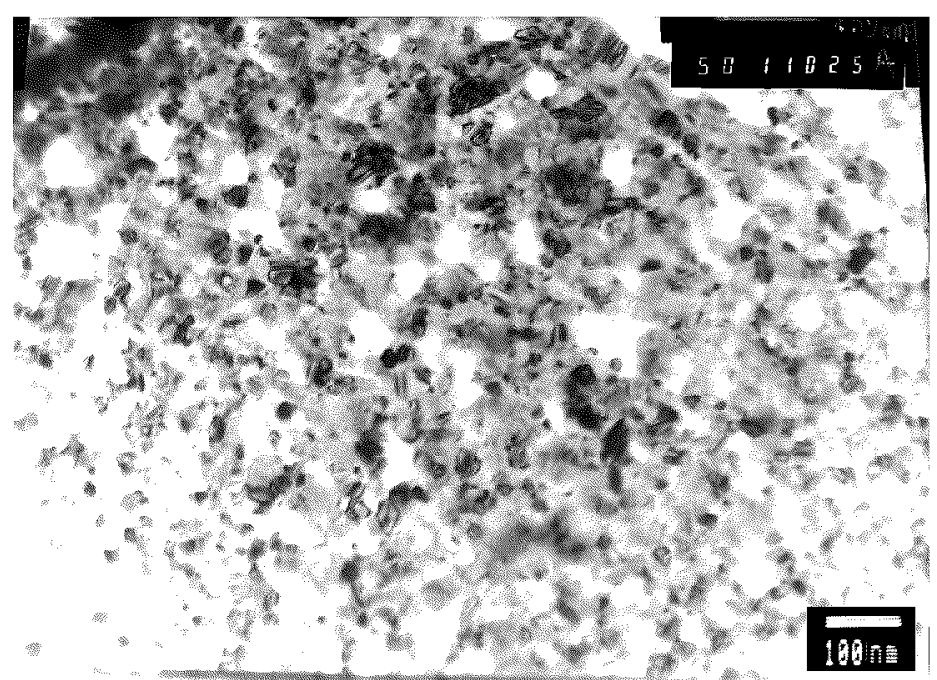

Fig. 3. TEM picture of the microstructure of Ni foil d.c.-plated from bath HKT-2000.

The hybrid coatings deposited from bath HKT-2000 had grains even $7 \mathrm{~nm}$ in size, with a predominance of 40-60 nm grains (Fig. 3). Defects in arrangement were already visible despite the small size of the grains. The grains are equiaxial and randomly oriented.

\subsection{Deposit properties}

The Table contains a comparison of the properties of the deposited layers.

TABLE

Properties of the electrodeposited nickel layers.

\begin{tabular}{|c|c|c|c|c|c|c|}
\hline Bath & $\begin{array}{c}\mu H V_{50}^{*} \\
\mathrm{kG} / \mathrm{mm}^{2}\end{array}$ & $\begin{array}{c}\text { Brightness } \\
\%\end{array}$ & $\begin{array}{l}\text { Roughness } \\
\qquad \mu \mathrm{m}\end{array}$ & $\begin{array}{l}\text { Depth of } \\
\text { wear, } \mu \mathrm{m}\end{array}$ & $\sum_{\% \text { weight }}$ & $\begin{array}{c}i_{\text {Corr }} \\
\mu \mathrm{A} / \mathrm{cm}^{2}\end{array}$ \\
\hline $\mathrm{L}-\mathrm{CB}$ & 235 & 0 & 0.55 & 16.7 & 0.037 & 0.45 \\
\hline KGN-97 & 695 & 64 & 0.19 & 16.1 & 0.147 & 0.81 \\
\hline HKT-2000 & 766 & 44 & 0.38 & 1.6 & 3.1 & 0.38 \\
\hline
\end{tabular}

*microhardnes at load $0.050 \mathrm{kG}$. 
The foil deposited from the low-concentration bath was characterized by a low microhardness, dullness, roughness, and low wear resistance. The nanonickel foil deposited from bath KGN-97 had a very high microhardness, low roughness, and low resistance to wear. High wear resistance and microhardness characterized the hybrid coating from $\mathrm{SiC}$ and PTFE. The corrosion current was the highest for deposits from bath KGN-97 and the lowest for the hybrid nanonickel layer. This indicates that inclusions that are incorporated in the nanonickel layer from bath KGN-97 have an unfavorable influence on its corrosion resistance. The dull deposit from the low-concentration bath had better corrosion resistance despite its large-grain structure (the content of non-metal inclusions was four times lower). Ceramic and polymer particles incorporated into the hybrid coating gives to this coating a very good resistance to corrosion because the metallic surface exposed to attack from the corrosion medium is reduced.

\section{Summary}

The presented results support the conclusion that a nanocrystalline structure of a nickel layer is not sufficient to obtain good functional properties. Strengthening the nanocrystalline nickel matrix with ceramic and polymer particles gave a positive effect in the form of high wear and corrosion resistance.

\section{References}

[1] M. El-Sherik, U. Erb, Plat. Surf. Finish. 82, 85 (1995).

[2] S. Shiram, S. Mohan, N.G. Renganathan, R. Venkatachalam, Trans. Inst. Metal Finish. 78, 194 (2000).

[3] N.V. Myung, M. Schwartz, K. Nobe, Plat. Surf. Finish. 87, 76 (2000).

[4] A. Wolkenberg, A. Tokarz, A. Bochenek, Z. Nitkiewicz, A. Banaszkiewicz, H. Wrzesińska, A. Kudła, Problemy Eksploatacji 2, 487 (2000).

[5] W. Schwarzacher, D.S. Lashmore, IEEE Trans. Magn. 32, 3133 (1996).

[6] N.V. Myung, K. Nobe, Plat. Surf. Finish. 87, 125 (2000).

[7] H. He, X. Jin, Z. Shen, J. Mater. Sci. Lett. 14, 913 (1995).

[8] I. Bakonyi, E. Toth-Kadar, L. Pogany, A. Cziraki, I. Geröcs, K. Varga-Josepovits, B. Arnold, K. Wetzig, Surf. Coat. Technol. 78, 124 (1996).

[9] R.T. Choo, J.M. Toguri, A.M. El-Sherik, U. Erb, J. Appl. Electrochem. 25, 384 (1995).

[10] T. Yamasaki, R. Tomohira, Y. Ogino, P. Schloßmacher, K. Ehrlich, Plat. Surf. Finish. 87, 148 (2000).

[11] C. Jakob, F. Erler, R. Nutsch, S. Steinhäuser, B. Wielage, A. Zschunke, Metaloberfläche 54, 50 (2000).

[12] L. Benea, P.L. Bonora, A. Borello, S. Martelli, G. Maurin, in: 51st ISE Meeting, Electrochemistry at the Turn of the Millennium, August 2000, Warsaw, http://alfa.chem.uw.edu.pl/ise 2000/ . 
[13] J.P. Celis, J.R. Roos, C. Buelens, J. Electrochem. Soc. 147, 1402 (1987).

[14] K. Helle, F. Walsh, Trans. Ins. Metal Finish. 75, 53 (1997).

[15] B. Szczygiel, Trans. Ins. Metal Finish. 73, 142 (1995).

[16] B. Szczygiel, Trans. Ins. Metal Finish. 75, 59 (1997).

[17] J.P. Celis, J. Fransaer, Trans. Ins. Metal Finish. 75, 118 (1997).

[18] G.N.K. Ramesh, S. Mohan, Plat. Surf. Finish. 4, 86 (1995).

[19] B. Szeptycka, J. Sztandor, A. Gwizdowski, Powtoki Ochronne 1-3, 49 (1992) (in Polish).

[20] B. Szeptycka, Kompozyty 2, 137 (2001) (in Polish). 